\title{
Challenges in implementing the National Sustainable Agriculture Development Plan (NSADP) for subsistence and semisubsistence farmers in Sierra Leone
}

\author{
Silvia Saravia-Matus \\ Sergio Gomez Y Paloma \\ European Commission - Joint Research \\ Centre \\ Institute for Prospective Technological \\ Studies (IPTS) \\ Calle Inca \\ Garcilaso \# 3 \\ Sevilla \\ Spain \\ <silvia.saraviamatus@yahoo.es> \\ <sergio.gomez-y-paloma@ec.europa.eu>
}

\begin{abstract}
The Government of Sierra Leone's National Sustainable Agriculture Development Plan (NSADP) 2010-2030 recommends the gradual eradication of shifting cultivation practices and the active promotion of vertically integrated processing and marketing chains for selected staples (mainly rice and cassava) and export crops (cocoa and coffee). This article examines the implications of the changing national agricultural policy for the subsistence and semisubsistence farmers who represent about two-thirds of the population of Sierra Leone. Using socioeconomic data from a 2009 survey of 600 farm-households located in the country's two main agricultural regions, we classified farms according to the diversity of the crops cultivated. The results illustrate the potential impact on rural livelihoods of the implementation of the NSADP and the challenges related to the transition period required to replace shifting cultivation with permanent agricultural systems.
\end{abstract}

Key words: crop diversification; livelihood strategies; National Sustainable Agriculture Development Plan (NSADP); (semi)-subsistence farming; Sierra Leone.

Subjects: farming systems; territory, land use, agricultural and food production policy.

\section{Résumé}

Défis de mise en œuvre du Plan national de développement agricole durable (NSADP) pour les petites exploitations de Sierra Leone

Le gouvernement de Sierra Leone a publié son Plan national de développement agricole durable (NSADP) 2010-2030 qui préconise l'éradication progressive des pratiques de culture itinérante (défriche-brûlis) et la promotion active de l'intégration verticale des filières de transformation et de commercialisation pour certaines denrées de première nécessité (principalement riz et manioc), et de produits destinés à l'exportation (cacao, café). L'article se propose d'examiner les conséquences du changement de la politique agricole nationale pour les agriculteurs de semi-subsistance, qui représentent environ deux tiers de la population de Sierra Leone. À cet effet, les typologies des systèmes d'exploitation sont présentées en fonction de la diversité des espèces cultivées. Nous avons utilisé les données socio-économiques d'une enquête menée en 2009 auprès de 600 exploitants agricoles des deux principales régions agricoles de Sierra Leone. Les résultats illustrent l'impact potentiel sur le niveau de vie en milieu rural de l'exécution du NSADP et les enjeux liés à la période de transition nécessaire au remplacement effectif des cultures itinérantes par des systèmes agricoles permanents.

Mots clés : agriculture de semi-subsistance ; stratégies agricoles ; niveau de vie ; diversification des cultures ; Plan national de développement agricole durable (NSADP) ; Sierra Leone.

Thèmes : systèmes agraires ; territoire, foncier, politique agricole et alimentaire.
Reprints: S. Saravia-Matus doi: 10.1684/agr.2015.0757
To cite this article: Saravia-Matus S, Gomez y Paloma S, 2015. Challenges in implementing the National Sustainable Agriculture Development Plan (NSADP) for subsistence and semisubsistence farmers in Sierra Leone. Cah Agric 24: 240-5. doi : 10.1684/agr.2015.0757 
I $\mathrm{n}$ this article, we review the agricultural situation in Sierra Leone from the point of view of the smallholders who are the majority not only of the agricultural sector but of the entire population. More importantly, we offer a preliminary assessment of the potential impact on their rural livelihoods of the implementation of the National Sustainable Agriculture Development Plan (NSADP) 2010-2030. This preliminary or stocktaking analysis is valuable and relevant since it provides a forum for reflection and improvement as the initial implementation phases of the NQADP (2010-2015) began. To conduct this analysis, we classified semisubsistence and subsistence (hereafter jointly described as semisubsistence) producers based on their crop portfolios to examine how these policy initiatives, mainly focused on the promotion of selected crops under permanent cultivation, are likely to affect smallholders currently using a shifting cultivation system in the short to middle term.

The background, dataset and scientific approach part of this paper presents an in-depth description of the dominant agricultural production system in Sierra Leone along with an overview of the dataset used to explore smallholders' production practices. The dataset was obtained from the assessment of the projects funded by the European Union Stabilization of Export Earnings (STABEX) in Sierra Leone, which had components similar to the NSADP initiatives, particularly in terms of crop-specific support (i.e. rice, coffee, and cocoa). In 2005, the government of Sierra Leone requested European Union STABEX funds to improve national rice production and rehabilitate cocoa and coffee plantations. Although the 2009 dataset was originally designed to examine the effect of STABEXfunded aid programs on smallholders, it provides accurate information on agricultural activity, output and performance of semisubsistence farmers in the country's largest agricultural regions. We include a technical literature review and survey information to establish a farm typology based on agroecological specifications, crop diversification, and market integration. The discussion of results and analysis of potential effects utilize the typology of semisubsistence farmers to highlight the challenges associated with the main components of NSADP strategies, related mainly to the transformation of shifting cultivation to a permanent agriculture system. The practical consequences to these semisubsistence smallholders and the possible obstacles they are likely to face in the short to middle term as the NSADP is implemented are also discussed. Concluding remarks summarize our conclusions.

\section{Background, dataset and scientific approach}

Agriculture is essential to Sierra Leone's economic and social development. While the agricultural population (circa 5 millions) represents roughly two thirds of total population, the agricultural sector in Sierra Leone in recent years has contributed less than $50 \%$ of GDP. Several factors hinder the economic performance of agriculture. First, the farming systems are characterized by highly inefficient input/output mixes that favor risk minimization over cash-income generation strategies. Pre- and post-harvest losses are also substantial, reaching 30\% of total output in many rural areas. The government of Sierra Leone launched the NSADP to address these issues by integrating smallholders into market value chains and introducing permanent agriculture systems that focus on selected export and staple crops (i.e. cocoa, coffee, and rice).

This analysis is based on primary data collected in 600 face-to-face interviews conducted in 2009 by the Institute of Prospective and Technological Studies of the Joint Research Centre of the European Commission (Gomez y Paloma et al., 2012). The 600 farmhouseholds observed in the survey were drawn from the most relevant agricultural areas of Sierra Leone in an attempt to obtain an accurate understanding of the nature of the smallholder agricultural population. Surveyed smallholders were thus spread between the Northern and Eastern Regions of the country, covering all relevant agricultural districts, chiefdoms, and villages. Sample sizes throughout the different areas are representative of the agricultural population in both regions (Northern and Eastern), five districts (Tonkolili, Bombali, Kono, Kenema and Kailahun), 11 chiefdoms, and 39 villages. Although the survey was originally intended to assess STABEX-funded projects in Sierra Leone, it effectively captured social and demographic traits, economic performance, and agricultural management data for smallholders there. The agricultural management data, in particular, are essential for understanding how smallholders operate in rural Sierra Leone. Besides its representativeness and the pertinence of the data, another main advantage of the survey is that it covers all forms of smallholder agricultural systems in Sierra Leone, with observations of all major agroecologies:

- the upland forest tree cropping system;

- the upland food cropping system; - the lowland (inland valley swamp and Boliland) food cropping system. While there is some overlapping of crop selection, there is a strong differentiation between the humid and subhumid areas, which may be described in relation to their agroecological settings and the different crop mixes. Humid zones located in the Eastern Region are defined by higher annual rainfall than the subhumid areas found in the Northern Region. Annual rainfall in humid areas is $1200 \mathrm{~mm}$ while in the subhumid areas it varies between 600 and $1200 \mathrm{~mm}$. Rain forest is the natural vegetation in humid tropical areas, while in the subhumid tropics, it is woodland with medium-totall grass ground cover. In Sierra Leone, the tree crops that can be grown in the subhumid areas differ from those in the humid zones. For instance, export tree crops such as coffee and cocoa benefit from the moisture of the rain forest and are planted mainly in the humid tropics. Other tree crops, such as oil palm, citrus trees, and sugar cane, are dominant in the subhumid areas and are mainly used for self-consumption or barter.

Although permanent cash tree cropping under forest (coffee and cocoa) is present in Sierra Leone, the most widespread form of agriculture is that of shifting cultivation. Under this system, also known as the slash and burn system, vegetation is cleared by 
partial felling of trees, burning, and planting of crops for a specific period of one or two years. The nutrients of the ash provide a rapid, initially lush growth of crop plants. However, much of the ash and the nutrients are lost through runoff or leaching. After harvest, the land is left uncultivated or idle for natural regeneration and quickly forms secondary forest (Mazoyer and Roudart, 2006). The idle intervals have been decreasing continuously in Sierra Leone since the 1960s, when this period lasted 20 years. Nowadays the idle period is closer to 4 to 7 years (NSADP, 2009). The consequent incomplete recovery of soil fertility contributes to declining yields. Several authors have already pointed out the danger of expanding cropping and reducing fallowing, which together increase the risk of environmental degradation (Bloom and Sachs, 1998; Mazoyer and Roudart, 2006). This explains in part why agriculture in Sierra Leone, although the largest single employer, contributed less than 50\% to GDP in 2006 and 2007 (UNDP, 2007).

Most farm households in Sierra Leone (approximately 400000 family farms) manage plots that do not exceed 2 cropped hectares (Sesay et al., 2004; Jalloh, 2006; SLIHS, 2007). All the major food crops are grown by smallholders under the shifting cultivation system: up to 15 different crops (sorghum, millet, maize, fundi (digitaria), benniseed, groundnuts, cowpeas, root crops and tubers including cassava roots, sweet potatoes, and yams, together with a host of vegetables) are traditionally grown in mixed stands, with rice as the dominant staple (Jalloh, 2006). The widespread crop diversification strategies appear to follow a food security objective since only a limited proportion of the yield is actually marketed. For rice, this proportion varies between 20\% and 60\% (Gomez y Paloma et al., 2012).

At the same time, smallholders face constraints in investing in agricultural equipment, due not only to the credit shortage in the sector but also to village-level institutional arrangements that do not support using land as collateral for loans. For instance, the notion that the enlarged farm-household family (including the dead and the unborn) must agree on land transactions represents a significant obstacle. Lastly, only the most basic agricultural equipment and tools (i.e. hand-hoes) are available, and the transport infrastructure is considered largely inadequate (Saravia-Matus and Gomez y Paloma, 2014).

We used a deductive approach to build a typology for semisubsistence farms in Sierra Leone (Saravia-Matus, 2013). The deductive approach, also known as a top-down or qualitative approach to typology building, uses preselected criteria to construct policy-relevant types. We used two main criteria. The first was the agroecological conditions described above, i.e., whether the farm is located in a humid or subhumid tropical climate. The second criterion addresses the degree of crop mix, through a count index (of species richness) and the degree of crop specialization/diversification on the farm, based on the percentage of area covered by each cultivated crop. This also indicates involvement in market exchanges, since farmers cultivating cocoa or coffee are fully integrated in output markets while farmers engaged mainly in staple crop production tend to channel a substantial amount of their yield towards self-consumption (Gomez y Paloma et al., 2012).

Surveyed farms were initially classified in terms of their agroecological location (i.e. humid and subhumid zones) and then categorized according to crop mix intensities; this produced 7 main types (table 1). Farm types may be further divided into crop subcategories, which are useful when evaluating the returns on farm activity within the same dominant farm type. One initial and relevant finding from table 1 is that fully specialized farms are not very widespread in the sample. For instance, Farm Type 1, which represents smallholders cultivating rice, accounts for only $11 \%$ of the total number of surveyed farms and just $2 \%$ of the total farm area studied. Farm net income per farm-household unit (FNI/HHunit) and acre per farmhousehold unit (acre/HHunit) are useful indicators for comparing farm types (FT) (FAO, 1999; Segre, 1999). In this survey, a farm-household is defined as a social unit where members share the same abode or home and pool resources for farming activities (Ellis, 2000). In Sierra Leone, a farm-household is a subset of an extensive family (Saravia-Matus and Gomez y Paloma, 2014). Farm net income at the farm-household level was calculated as follows: $(\mathrm{FNI})=$ Gross Production Value (GPV) - Input Costs (IC) where GPV = Farm Production * Market price; IC include both variable and fixed costs (variable costs $=$ cost of labor and other inputs; fixed costs $=$ cost of tools and land rent payments) (Saravia-Matus and Gomez y Paloma, 2014). A farm-household unit (HHunit) was calculated as the sum of adult-equivalent household members (Gomez y Paloma et al., 2012). The adult equivalent transformation is based on the following standards: adult male $=1$; adult female $=0.75$; child $7-10$ years old $=0.69$; child $4-6$ years old $=0.62$; child $0-3$ years old $=0.45$ (Fagernäs and Wallace, 2007). The introduction of the HHunit allows for straightforward comparisons in terms of FNI and farm area across types. Figure 1 below reports the FNI/ HHunit and acre/HHunit indicators for the 7 farm types identified and their respective subcategories. Farmers who cultivate cocoa and coffee along with other staple and tree crops (i.e. FT5, FT6 and FT7) have substantially higher incomes per farm-household unit than all the types of farms in the subhumid zone, where these trees cannot be grown. The finding that the FNI/HHunit of FT5, FT6 and FT7 is on average 8 to 10 times higher than the other FTs with similar land endowments suggests that their yields are also higher. It is interesting to note, however, that FT5 and FT6, which report the highest earnings, maintain mixed agricultural systems, planting both cash tree crops and staples. According to Govereh and Jayne (2003), participation in cash crop schemes (especially under conditions of credit and input market failure) may enable farm-households to acquire key inputs and skills that can be used to increase the productivity of other crops in their mix; they can thus exploit synergies between cash crops and food crops not only in production but also in commercialization. The close up in figure 1 for the segment of FTs with lower income levels illustrates that crop diversification is an important livelihood strategy in subhumid zones because the FTs with diversified crop portfolios have relatively higher FNI levels. 


\section{Table 1. Farm typology in Sierra Leone (based on survey findings).}

Tableau 1. Typologie des exploitations agricoles en Sierra Leone (basée sur les résultats de l'enquête).

\begin{tabular}{|c|c|c|c|c|}
\hline $\begin{array}{l}\text { Farm Type (FT): } \\
\text { Avg FNI/HHunit in } \\
\text { Leones - Acre/HHunit }\end{array}$ & Abbreviation* & Description & $\begin{array}{l}\text { Number (\%) of } \\
\text { farms per FT }\end{array}$ & $\begin{array}{c}\text { Total area } \\
\text { per FT }\end{array}$ \\
\hline
\end{tabular}

Sub-Humid Areas:

\begin{tabular}{|c|c|c|c|c|}
\hline FT 1: $14,700-0.44$ & $\mathrm{R}$ & $\begin{array}{l}\text { Rice only or rice as the dominant } \\
\text { crop ( } 90 \% \text { of cultivated area) }\end{array}$ & $64(11 \%)$ & $2 \%$ \\
\hline FT 2: $66,409-0.74$ & $R+S$ & Rice and other staple crops & $64(11 \%)$ & $4 \%$ \\
\hline FT $3: 71,664-1.50$ & $\mathrm{R}+\mathrm{T}-\mathrm{cc}$ & $\begin{array}{l}\text { Rice and tree crops (oil palm, and/or } \\
\text { citrus trees or other trees) }\end{array}$ & $99(16 \%)$ & $9 \%$ \\
\hline FT 4: 83,584-0.86 & $\mathrm{R}+\mathrm{S}+\mathrm{T}-\mathrm{cc}$ & $\begin{array}{l}\text { Rice, other staple crops and tree crops } \\
\text { (oil palm and/or citrus) }\end{array}$ & $165(27 \%)$ & $23 \%$ \\
\hline
\end{tabular}

\section{Humid Areas:}

\begin{tabular}{lccc}
\hline FT 5: $930,912-1.72$ & $\mathrm{R}+\mathrm{cc}$ & Rice and cocoa \& coffee trees & $36(6 \%)$ \\
\hline FT 6: $862,644-2.11$ & $\mathrm{R}+\mathrm{S}+\mathrm{T}+\mathrm{cc}$ & $\begin{array}{c}\text { Rice, other staple \& tree crops and } \\
\text { cocoa \& coffee trees }\end{array}$ & $73(12 \%)$ \\
\hline FT 7: $696,674-1.40$ & $\mathrm{cc}+\mathrm{T}_{\text {oil palm }}$ & Cocoa \& coffee trees and oil palm & $94(16 \%)$
\end{tabular}

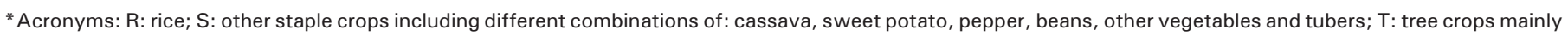


FNI in Leones; 1 Euro $=4400$ Leones.

Source : Own elaboration based on 2009 Sierra Leone Survey on STABEX initiatives (Gomez y Paloma et al., 2012).

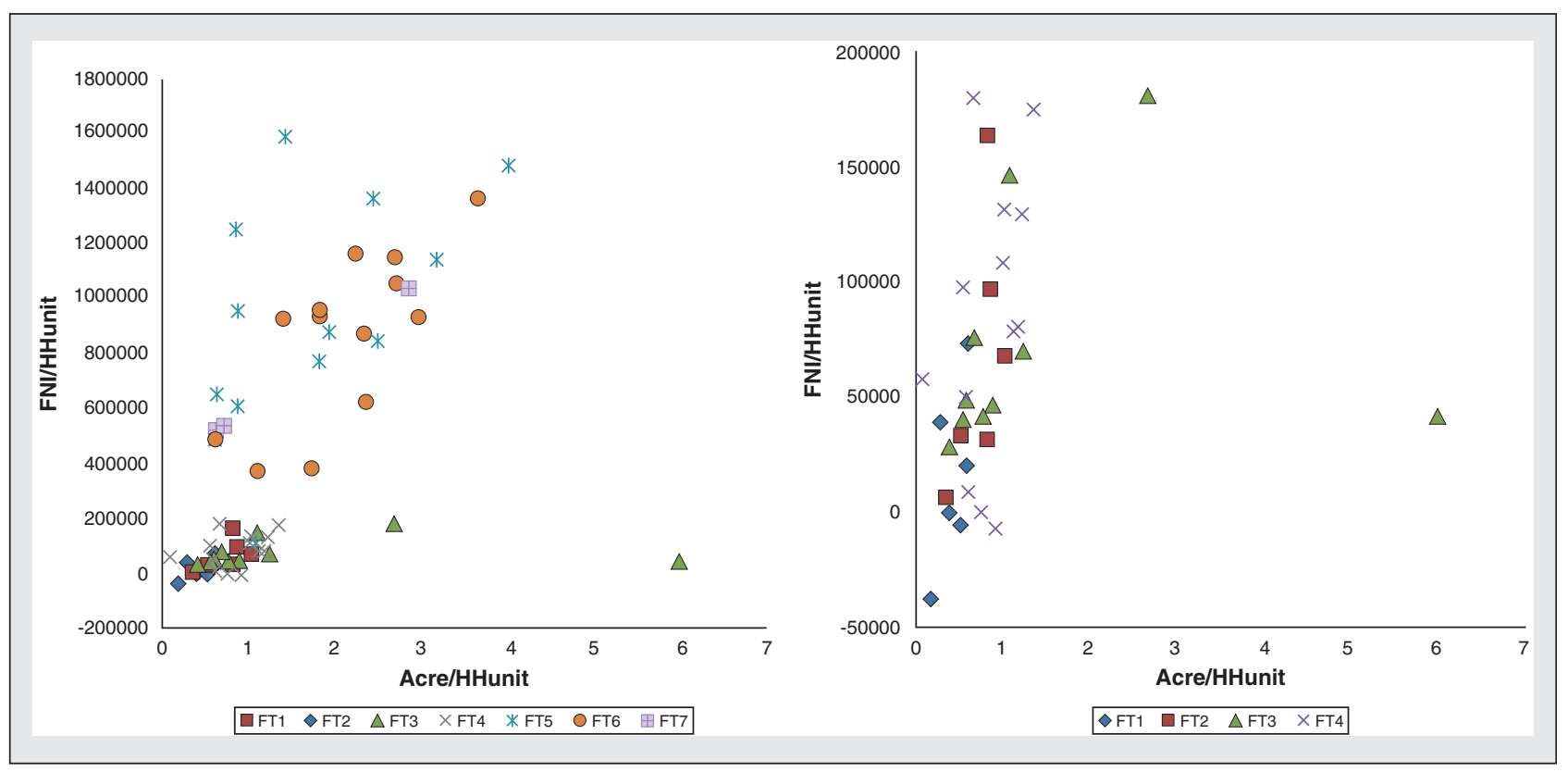

Figure 1. FNI/HHunit (in Leones) \& Acre/HHunit by farm type (overall and close-up on low income farms).

Figure 1. FNI / HHunit (en Leone) et Acre / HHunit par type d'exploitation agricole (vue d'ensemble et gros plan sur les revenus les plus faibles). Source : Own elaboration based on 2009 Sierra Leone Survey on STABEX initiatives (Gomez y Paloma et al., 2012). 
Farms growing mainly rice (FT1) report the lowest income levels, which reflect a generally lower productivity per acre. But farmers who cultivate a wider variety of crops (FT2, FT3 and FT4) are able to achieve higher yields and thus reach relatively higher FNI levels with equivalent land endowment per farm household unit.

\section{Discussion of results}

\section{in the light of the} main components of the NSADP and the stock-taking analysis of potential effects

\section{on semisubsistence}

\section{farmers}

In this section, we discuss the NSADP components relevant for semisubsistence farmers and evaluate their potential policy impact on and the challenges they present for the livelihood of the farm types we have identified, most of them characterized by diversified crop portfolios under intercropping cultivation strategies. One key aspect of the NSADP strategic program is to promote the replacement of the shifting cultivation system as a way to improve current productivity (NSADP, 2009). This strategy, however, implies a change in smallholders' crop diversification and selfconsumption strategies for which farmers must be prepared. The NSADP (2009) focuses on a move towards permanent cultivation of food crops (mainly rice and cassava), promotion of export tree crops (i.e. cocoa and coffee), the introduction of inorganic fertilization, and integrated commercialization programs (NSADP, 2009).

The government is pursuing this 20-year plan by making much-needed improvements to rural infrastructure, agricultural research and extension services, farmer capacity building, and support for productivity and marketing-enhancing activities (i.e. mechanization, revision of land policy, credit, and crop-specific market access, etc.) (NSADP, 2009). The main aspects requiring analysis from the point of view of semisubsistence smallholders' current livelihoods include the technical and socioeconomic challenges of replacing shifting cultivation and the introduction of permanent commercial agriculture. The latter presents challenges, specifically, the establishment of processing facilities and distribution chains that would include small-scale farmers. Sustainable biodiversity conservation is another important issue, along with helping semisubsistence farm-households to decide between self-consumption and market integration.

With increasing population pressure and falling soil fertility, it is clear that the sustainability of the shifting cultivation system is uncertain in Sierra Leone. Under the NSADP (2009), the government would like to discourage this system in favor of a higher value permanent cropping system with more sustainable tree and food cropping. However, it is no straightforward matter to introduce this kind of system in Sierra Leone. For instance, if permanent cultivation is promoted, not only must a timely supply of mainly imported inputs such as fertilizers, machinery, and fuel be ensured for a large number of smallholders dispersed in remote areas, but adequate training must also be provided. This translates into higher dependence on international markets and agricultural research, which does not currently focus adequately on the needs of tropical agricultural systems (Pingali, 2007). If chemical fertilizers and improved seeds are to be used, effective training is essential to reduce land pollution and deterioration in the case of the former and achieve higher yields for the latter. The impact of introducing new equipment or machinery is also not entirely clear, for it might either release labor to the off-farm sector or increase the rate of deforestation. However, machinery could be a solution to harvest losses that are due to labor shortages in peak periods. It is also essential to review how the labor requirements of a permanent cultivation system will be met. Currently, it is the number of family members that determines the size of the cultivated area in Sierra Leone rather than the actual total land area available to the family.
Similarly, the integration of smallholders into vertically integrated market value chains is not without difficulties. Smallholders must first generate sufficient output for selfconsumption before they can devote additional output for sales. Several production and transaction costs affect this decision-making process. Smallholders need to boost productivity levels; to do so, they require additional training as well as ready access to technology and inputs that increase yields (Barret, 2008). Agricultural productivity growth depends on functioning input distribution systems and vice versa (Jama and Pizarro, 2008). In other words, farmers must be aware of what technologies work best, know how to use them, and generate effective demand for viable new technologies to provide signals to the input distribution system to supply them.

As Kelly et al. (2003) have underlined, without a serious commitment to providing basic public goods, it is unlikely that large-scale government input subsidies, credit access, and distribution programs will have any lasting impact on agricultural intensification, rural incomes, national food security, or poverty reduction. Consequently, governments must focus on public goods as a prerequisite that will encourage farmers to intensify agricultural production and encourage the private sector to expand commercial input supply. In Sierra Leone, the inadequacy of rural roads and the lack of sufficient storage, particularly during the rainy season, cause substantial post-harvest losses (Gomez y Paloma et al., 2012). Costs of exchange and transport may thus hinder market access in terms of spatial price transmission and trade competition. This situation would lead to leaner, more volatile markets that would further limit smallholders' incentives to increase productivity so that they could generate marketable surpluses (Barrett, 2008). Although the NSADP (2009) anticipates a strong investment in infrastructure, it must be carried out in a timely manner.

The results of the typology and survey data indicate that smallholders in Sierra Leone are extensively engaged in crop diversification strategies aimed at securing a minimum consumption level and minimizing external risks related to accessing markets, 
particularly in the subhumid agroecologies. This crop diversification strategy also responds to the economic background, where access to yieldincreasing technology, inputs and credit is limited. Consequently, the government objective of increasing single-crop cultivation and vertically integrated production chains in these areas must be based on a wellspecified transition program that allows smallholders to fulfill basic food security levels as they find new and reliable output and input market and/or job opportunities in singlecrop cultivation and commercialization programs. If this does not happen, the partial food security effect currently achieved through crop diversification will no longer exist and smallholder vulnerability may be expected to increase sharply. To supplement farm-household incomes during the transition, the government should accompany NSADP with an overall strategy to boost the rural economy. This strategy should cover not only other agriculture-related sectors, such as fishery or forestry, which are already included in NSADP, but other inter-related sectors such as trading, manufacturing, and construction, which could provide further opportunities in nonagricultural yet rural contexts.

\section{Concluding remarks}

The NSADP illustrates that the government of Sierra Leona is aiming to increase production and marketing through intensified production of selected food crops (rice and cassava), and traditional tree crops (coffee, cocoa). The survey data provides evidence of the importance of crop diversification strategies at the smallholder level, which will enable them to meet their food security goals. In farm-households where agroenvironmental conditions prevent the cultivation of traditional export tree crops such as cocoa and coffee, the diversification of staple crops is preferable to and more widespread than single- crop cultivation. Therefore, the government will have to create substantial transaction benefits to promote cropspecific commercialization in the main agricultural areas of the country. These benefits should be accompanied by an overall incentive package that addresses the entire rural economy in Sierra Leone.

In short, if the government refuses to improve shifting cultivation, there are two main challenges for the implementation of the NSADP:

- the necessary transition period between shifting cultivation and permanent agriculture;

- the economic sustainability of the permanent agriculture system, which relies on a well-functioning input distribution service and accessible output markets.

In the first case, short-term food security and employment opportunities (in both rural and urban areas) must be considered for smallholders. In the second, market organization is crucial, particularly for the supply of key inputs such as fertilizers or pesticides. One important feature of this supply network is that it would include hundreds of thousands of smallholders located in remote areas of the country.

\section{Acknowledgements}

The research leading to these results has received funding from the European Union's Seventh Framework Programme FP7/2007-2011 under Grant Agreement $\mathrm{n}^{\circ} 290693$ FOODSECURE and from the Joint Research Centre of the European Commission (JRC). The funders had no role in study design, data collection and analysis, decision to publish, or preparation of the manuscript. FOODSECURE and any of its partner organizations, any organization of the European Union or the European Commission are accountable for the content of this article.

\section{References}

Barrett CB, 2008. Smallholder market participation: concepts and evidence from eastern and southern Africa. Food Policy;299-317.
Bloom DE, Sachs JD, 1998. Geography, demography, and economic growth in Africa. Brookings Papers on Economic Activity 2.

Ellis F, 2000. Rural livelihoods and diversity in developing countries. Oxford: Oxford University Press.

FAO, 1999. Guidelines for agrarian systems diagnosis. Rome: Food and Agriculture Organization.

Fagernäs S, Wallace L, 2007. Determinants of poverty in Sierra Leone 2003. ESAU Working Paper 19. London: Overseas Development Institute.

Gomez y Paloma S, Acs S, Saravia-Matus S, et al. 2012. Rural poverty reduction and food security: the case of smallholders in Sierra Leone. EC-JRCIPTS Technical Report EUR Number: 25264 EN. Seville: Publications Office of the European Union.

Govereh J, Jayne TS, 2003. Cash cropping and food crop productivity: synergies or trade-offs? Agricultural Economics 28(1):39-50.

Jalloh A, 2006. Country study: Sierra Leone agricultural and rural cooperation. CTA July 2006. Project 4-7-41-2007/5b.

Jama B, Pizarro G, 2008. Agriculture in Africa: strategies to improve and sustain smallholder production systems. Ann NY Acad Sci 1136: 218-32.

Kelly V, Adesina AA, Gordon A, 2003. Expending access to agricultural inputs in Africa: a review of recent market development experience. Food Policy 28:379-404.

Mazoyer M, Roudart L, 2006. A history of world agriculture: from the neolithic age to the current crisis. New York: Monthly Review Press.

NSADP, 2009. National sustainable agriculture development Plan 2010-2030. Sierra Leone.

Pingali $\mathrm{P}, 2007$. Will the gene revolution reach the poor? - Lessons from the green revolution. 7th Manshold Lecture. Wageningen, January 26, 2007.

Saravia-Matus S. with support from Cimpoies D and Ronzon T, 2013. Typology and indicators to characterize agricultural holdings for improved policy. Roma: World Agriculture Watch (WAW).

Saravia-Matus S, Gomez y Paloma S, 2014. Farm viability of (semi) subsistence smallholders in Sierra Leone. The African Journal of Agricultural and Resource Economics 9(3):165-82.

Segre A, (Ed), 1999. Agricultural and environmental issues for sustainable development in albania. an agrarian system analysis-diagnosis in Divjaka Region. BESA.

Sesay A, Tejan-Kella M, Thompson A, 2004. Agricultural sector, Background review for the PRSP. Sierra Leone.

SLIHS, 2007. Sierra Leone integrated household survey (SLIHS) 2003/04. Department for International Development, Government of Sierra Leone.

UNDP, 2007. Sierra Leone human development report, empowering local government for sustainable development and poverty reduction. Sierra Leone: United Nations Development Programme. 